\section{Combination Sprays with Benzyladenine to Chemically Thin Spur-type 'Delicious' Apples}

\author{
Duane W. Greene and Wesley R. Autio \\ Department of Plant and Soil Sciences, University of Massachusetts, Amherst, \\ MA 01003
}

Additional index words. Malus domestica, growth regulator, BA, NAA, carbaryl, flowering, fruit set, postharvest quality, seed number

Abstract. BA, NAA, and carbaryl at 75, 6, and $600 \mathrm{mg}^{-l_{\text {liter }}}{ }^{-1}$, respectively, were applied alone or in combination to 'Starkrimson Delicious' in 1989 and 'Redspur Delicious' apples (Malus domestica Borkh.) in 1990. BA was effective alone, but when combined with carbaryl it thinned excessively. Thinning failed when BA was combined with NAA because many seedless pygmy fruit were formed and they persisted until harvest. BA and carbaryl were more effective than NAA at increasing return bloom. Return bloom was more closely related to total seed count than to final set. BA improved flesh firmness at harvest and after cold storage. None of the treatments influenced the development of calcium-related storage disorders following air storage. Chemical names used: benzyladenine (BA); naphthaleneacetic acid (NAA).

Chemical thinning continues to be one of the more important management techniques in successful orchard operations (Looney, 1986). Removing a sufficient number of developing fruit soon after initial set promotes good fruit size at harvest and assures adequate repeat bloom (Williams and Edgerton, 1981).

Some cultivars, such as spur-type 'Delicious', are more difficult to thin than others (Williams and Edgerton, 1981). Thus, an aggressive thinning program is usually required. Carbaryl and NAA are the primary chemical thinners used on 'Delicious' in the northeastern United States (Forshey, 1987). Carbaryl is a relatively mild thinner that frequently does not thin adequately when used alone (Williams, 1979). Its usefulness is further limited because it is toxic to some mite predators important in integrated pest management (Hislop and Prokopy, 1981). NAA is a more potent thinner; however, when applied at concentrations that thin adequately, it may cause pygmy fruit formation, or may overthin under some conditions (Bound et al., 1991a; Miller, 1985; Rogers and Williams, 1977). In a frequently used strategy, carbaryl plus NAA are applied at lower rates to thin while reducing the potential for undesirable side effects (Forshey, 1987; Grauslund, 1981).

BA has been an effective thinner on diverse cultivars, including 'McIntosh' (Greene and Autio, 1989), 'Empire' (Elfving, 1991; Greene and Autio, 1990), 'Golden Delicious' (Greene and Autio, 1990; McLaughlin and

Received for publication 18 Oct. 1993. Accepted for publication 5 Mar. 1994. Massachusetts Agricultural Experiment Station, Univ. of Massachusetts at Amherst. This research was supported in part by Experiment Station Project no. 696. The cost of publishing this paper was defrayed in part by the payment of page charges. Under postal regulations, this paper therefore must be hereby marked advertisement solely to indicate this fact.
Greene, 1984), 'Idared' (Elfving, 1989), and red 'Fuji' (Bound et al., 1991b). BA may thin 'Delicious', but unacceptably high rates may be required that may decrease seed count, reduce red pigmentation, and stimulate spur elongation and branching (Greene, 1993). These undesirable side effects diminish when used. BA has been combined with carbaryl and NAA to effectively thin 'McIntosh' (Greene and Autio, 1990).

This investigation was undertaken to detaining BA could reduce crop load on 'Delicious' without undesirable side effects. lower rates of carbaryl, NAA, and BA are termine if chemical thinner combinations con(1990) of mature 'Starkrimson Delicious'/M.7.
'Starkrimson Delicious', 1989. Mature 'Starkrimson Delicious'/M.7 apple trees growing at the Univ. of Massachusetts Horticultural Research Center, Belchertown, were blocked into eight groups of eight trees each. At the pink stage of flower development, two limbs per tree, 10 to $15 \mathrm{~cm}$ in diameter, were tagged, and all blossom clusters were counted. On 2 June 1989, 17 days after full bloom (DAFB), one tree in each block was sprayed to the drip point with BA at $75 \mathrm{mg} \cdot \mathrm{liter}^{-1}$, NAA at $6 \mathrm{mg} \cdot \mathrm{liter}^{-1}$, or carbaryl at $600 \mathrm{mg} \cdot$ liter $^{-1}$ either alone or in all possible combinations. One unsprayed tree served as a control. At the end of the June-drop period, the total number of fruit persisting on each tagged limb was counted.

At the normal commercial harvest time, a 30-fruit sample was randomly harvested from each tree and weighed. Ten representative fruit per sample were selected and the flesh firmness determined with an Effegi penetrometer (Effegi, Alfonsine, Italy) (two punctures/ fruit, 11-mm head). Juice was collected during the firmness test, and soluble solids concentration (SSC) was determined using a hand refractometer on a composite juice sample. The number of viable-appearing seeds in each fruit was counted. Return bloom the following year was estimated by counting the flower clusters on two representative limbs per tree.

'Redspur Delicious', 1990. Mature 'Redspur Delicious'/M.7 in the same orchard were used for an experiment similar to that described previously, with treatments applied on 1 June 1991 (21 DAFB). All fruit in the 30apple random sample were initially weighed and the samples weighed again after all fruit $5.75 \mathrm{~cm}$ in diameter or smaller (pygmy fruit) were removed.

Table 1. Effects of BA, NAA, and carbaryl used alone or in combination on fruit set (1989) and return bloom

\begin{tabular}{|c|c|c|c|c|c|}
\hline \multirow[b]{2}{*}{ Treatment $^{\mathrm{z}}$} & \multirow{2}{*}{$\begin{array}{c}\text { Blossom } \\
\text { clusters/ } \\
\text { cm limb } \\
\text { cross-section } \\
\text { area } \\
(1989) \\
\end{array}$} & \multicolumn{2}{|c|}{ Fruit per } & \multirow{2}{*}{$\begin{array}{c}\text { Seeds/ } \\
\text { cm limb } \\
\text { cross-section } \\
\text { area } \\
(1989) \\
\end{array}$} & \multirow{2}{*}{$\begin{array}{c}\text { Blossom } \\
\text { clusters/ } \\
\text { cm limb } \\
\text { cross-section } \\
\text { area } \\
(1990) \\
\end{array}$} \\
\hline & & $\begin{array}{c}\mathrm{cm} \operatorname{limb} \\
\text { cross-section } \\
\text { area } \\
(1989)\end{array}$ & $\begin{array}{c}\text { 100-blossom } \\
\text { clusters } \\
(1989)\end{array}$ & & \\
\hline Control & 12.6 & 6.0 & 49 & 35.4 & 3.3 \\
\hline NAA 6 mg.liter ${ }^{-1}$ & 12.2 & 4.5 & 39 & 27.4 & 6.0 \\
\hline Carbaryl $600 \mathrm{mg} \cdot$ liter $^{-1}$ & 12.3 & 2.6 & 22 & 13.0 & 11.4 \\
\hline BA $75 \mathrm{mg} \cdot \mathrm{liter}^{-1}$ & 12.4 & 2.5 & 25 & 13.9 & 12.3 \\
\hline BA + carbaryl & 12.6 & 0.5 & 4 & 1.4 & 15.7 \\
\hline $\mathrm{BA}+\mathrm{NAA}$ & 12.6 & 5.6 & 49 & 6.3 & 11.2 \\
\hline NAA + carbaryl & 12.0 & 2.2 & 18 & 12.2 & 9.7 \\
\hline $\mathrm{BA}+\mathrm{NAA}+$ carbaryl & 12.5 & 4.7 & 45 & 0.2 & 15.0 \\
\hline \multicolumn{6}{|l|}{ Significance } \\
\hline NAA - & $12.5^{\mathrm{Ns}}$ & $4.2^{* *}$ & $38^{* * *}$ & $15.9^{* *}$ & $10.7^{\mathrm{Ns}}$ \\
\hline+ & 12.5 & 2.9 & 25 & 11.5 & 10.5 \\
\hline Carbaryl - & $12.5^{\mathrm{Ns}}$ & $4.7^{* * * *}$ & $41^{* * * *}$ & $20.8^{* * * *}$ & $8.2^{* * *}$ \\
\hline+ & 12.4 & 2.5 & 22 & 6.7 & 13.0 \\
\hline $\mathrm{BA}-$ & $12.3^{\mathrm{Ns}}$ & $3.8^{\mathrm{Ns}}$ & $32^{\mathrm{Ns}}$ & $22.0^{* * *}$ & $7.6^{* * *}$ \\
\hline+ & 12.5 & 3.3 & 31 & 5.5 & 13.5 \\
\hline NAA $\times$ carbaryl & NS & $* *$ & NS & $*$ & NS \\
\hline $\mathrm{NAA} \times \mathrm{BA}$ & NS & $* * *$ & $* *$ & NS & NS \\
\hline Carbaryl $\times$ BA & NS & NS & NS & NS & NS \\
\hline NAA $\times$ carbaryl & & & & & \\
\hline$\times \mathrm{BA}$ & NS & NS & NS & NS & * \\
\hline
\end{tabular}

${ }^{\mathrm{z}}$ Treatments applied 2 June 1989 (full bloom +17 days), as a dilute spray. ns, *,**,***N Nonsignificant or significant at $P \leq 0.05,0.01$, or 0.001 , respectively. 
In addition, a 20-kg fruit sample was collected from each tree at normal harvest and placed in regular air storage at $0 \mathrm{C}$ for 28 weeks. At the end of the storage period, flesh firmness on a 10-apple sample was determined as previously described. Fruit were kept at room temperature for 20 days at $\approx 20 \mathrm{C}$, until storage disorders developed. All fruit in the storage sample were assessed for senescent breakdown, bitter pit plus cork spot, and fruit decay.

Statistical analysis. To assess treatment effects, analyses of variance (ANOVA) were conducted using the ANOVA procedure of SAS 6.04 (SAS Institute, Cary, N.C.).

\section{Results}

Application of NAA or carbaryl significantly reduced crop load on 'Starkrimson Delicious' (Table 1). BA alone reduced crop load to a level comparable to that with carbaryl, but BA plus NAA resulted in little or no thinning. This combination resulted in many pygmy fruit that persisted until harvest. The BA plus carbaryl treatment nearly defruited the trees. All chemical thinners reduced the number of seeds when expressed on a per limb cross-sectional area basis. Only BA and carbaryl, however, enhanced return bloom, regardless of the combination. NAA only enhanced return bloom when compared to nontreated trees. NAA had no additional effect if another thinner was included.

The second experiment, on 'Redspur Delicious', confirmed several important observations. BA alone at $75 \mathrm{mg} \cdot \mathrm{liter}^{-1}$ appeared to thin as well as NAA at $6 \mathrm{mg} \cdot \mathrm{liter}^{-1}$ or carbaryl at $600 \mathrm{mg}$ liter $^{-1}$ (Table 2). When BA and NAA were combined, pygmy fruit were formed and thinning did not occur. The BA and carbaryl combination nearly eliminated the crop, even in years characterized by very heavy set. All chemicals reduced seed counts, but only carbaryl and BA increased return bloom as a main effect.

Chemical thinners alone consistently resulted in heavier fruit; however, when BA and NAA were combined, average fruit weight was reduced relative to the control (Table 3 ). In 1990, fruit weight was initially taken on all 'Redspur Delicious' and then again on the same fruit sample with all of the pygmy fruit removed (Table 4). As with 'Starkrimson Delicious', BA and carbaryl resulted in heavier fruit. The combination of BA and NAA caused lighter fruit, even if pygmies were removed. NAA alone or in combination with carbaryl had no effect on overall fruit weight, but when pygmies were eliminated, it appeared to increase weight.

In both experiments, NAA had little influence on flesh firmness while BA and carbaryl increased it. Overall, NAA reduced SSC while carbaryl and BA increased it, but the absolute differences were small, mostly $\leq 0.5$ (Tables 3 and 4).

Chemical thinners caused a small reduction in seed count (Tables 3 and 4). In combination, however, the effects were more pronounced, with combinations containing

Table 2. Effects of BA, NAA, and carbaryl used alone or in combination on fruit set (1990) and return bloom (1991) of mature 'Redspur Delicious'/M.7.

\begin{tabular}{|c|c|c|c|c|c|}
\hline \multirow[b]{2}{*}{ Treatment $^{\mathrm{z}}$} & \multirow{2}{*}{$\begin{array}{c}\text { Blossom } \\
\text { clusters/ } \\
\text { cm limb } \\
\text { cross-section } \\
\text { area } \\
(1990)\end{array}$} & \multicolumn{2}{|c|}{ Fruit per } & \multirow{2}{*}{$\begin{array}{c}\text { Seeds/ } \\
\text { cm limb } \\
\text { cross-section } \\
\text { area } \\
(1990)\end{array}$} & \multirow{2}{*}{$\begin{array}{c}\begin{array}{c}\text { Blossom } \\
\text { clusters/ }\end{array} \\
\text { cm limb } \\
\text { cross-section } \\
\text { area } \\
(1991)\end{array}$} \\
\hline & & $\begin{array}{c}\text { cm limb } \\
\text { cross-section } \\
\text { area } \\
(1990)\end{array}$ & $\begin{array}{c}\text { 100-blossom } \\
\text { clusters } \\
(1990)\end{array}$ & & \\
\hline Control & 12.8 & 11.9 & 90 & 72.4 & 2.5 \\
\hline NAA $6 \mathrm{mg} \cdot$ liter $^{-1}$ & 12.7 & 6.2 & 60 & 29.3 & 7.1 \\
\hline Carbaryl $600 \mathrm{mg} \cdot$ liter $^{-1}$ & 13.1 & 5.9 & 53 & 27.5 & 9.1 \\
\hline BA $75 \mathrm{mg} \cdot \mathrm{liter}^{-1}$ & 12.7 & 4.3 & 41 & 24.6 & 12.9 \\
\hline BA + carbaryl & 12.8 & 0.9 & 7 & 2.6 & 15.5 \\
\hline $\mathrm{BA}+\mathrm{NAA}$ & 13.9 & 10.7 & 86 & 15.6 & 8.8 \\
\hline NAA + carbaryl & 12.9 & 5.7 & 52 & 19.0 & 9.8 \\
\hline $\mathrm{BA}+\mathrm{NAA}+$ carbaryl & 12.5 & 6.1 & 48 & 6.7 & 14.8 \\
\hline \multicolumn{6}{|l|}{ Significance } \\
\hline NAA - & $12.9^{\mathrm{Ns}}$ & $5.8^{\mathrm{Ns}}$ & $48^{*}$ & $31.8^{*}$ & $10.0^{\mathrm{Ns}}$ \\
\hline+ & 13.1 & 7.2 & 61 & 17.6 & 10.1 \\
\hline Carbaryl - & $13.0^{\mathrm{Ns}}$ & $8.3^{* *}$ & $69^{* * * *}$ & $35.5^{* * *}$ & $7.8^{* * * *}$ \\
\hline+ & 12.9 & 4.7 & 40 & 13.9 & 12.3 \\
\hline $\mathrm{BA}-$ & $12.9^{\mathrm{Ns}}$ & $7.4^{*}$ & $64^{*}$ & $37.1^{* *}$ & $7.1^{* * * *}$ \\
\hline+ & 13.0 & 5.5 & 45 & 12.3 & 13.0 \\
\hline NAA $\times$ carbaryl & NS & NS & NS & $*$ & NS \\
\hline $\mathrm{NAA} \times \mathrm{BA}$ & NS & $* * *$ & $* * *$ & $* *$ & $*$ \\
\hline Carbaryl × BA & NS & NS & NS & NS & NS \\
\hline NAA $\times$ carbaryl & & & & & \\
\hline$\times \mathrm{BA}$ & NS & $*$ & NS & NS & $*$ \\
\hline
\end{tabular}

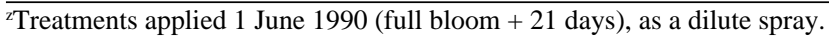

Ns, *,**,*** Nonsignificant or significant at $P \leq 0.05,0.01$, or 0.001 , respectively.

Table 3. Effects of BA, NAA, and carbaryl used alone or in combination on fruit characteristics of mature 'Starkrimson Delicious'/M.7.

\begin{tabular}{|c|c|c|c|c|}
\hline Treatment $^{\mathrm{z}}$ & $\begin{array}{c}\text { Fruit } \\
\text { wt } \\
(\mathrm{g})\end{array}$ & $\begin{array}{c}\text { Flesh } \\
\text { firmness } \\
(\mathrm{N})\end{array}$ & $\begin{array}{c}\text { Soluble } \\
\text { solids concn } \\
(\%)\end{array}$ & $\begin{array}{c}\text { Seed } \\
\text { count } \\
\text { (no.) }\end{array}$ \\
\hline Control & 143 & 77.1 & 10.7 & 6.0 \\
\hline NAA 6 mg·liter ${ }^{-1}$ & 152 & 76.6 & 10.9 & 6.0 \\
\hline Carbaryl 600 mg. liter $^{-1}$ & 157 & 77.1 & 11.8 & 5.0 \\
\hline BA $75 \mathrm{mg} \cdot$ liter $^{-1}$ & 168 & 79.8 & 11.5 & 5.4 \\
\hline BA + carbaryl & 170 & 82.6 & 12.2 & 3.0 \\
\hline $\mathrm{BA}+\mathrm{NAA}$ & 128 & 81.2 & 11.0 & 1.3 \\
\hline NAA + carbaryl & 163 & 77.1 & 11.6 & 5.6 \\
\hline $\mathrm{BA}+\mathrm{NAA}+$ carbaryl & 116 & 83.9 & 12.2 & 0.1 \\
\hline \multicolumn{5}{|l|}{ Significance } \\
\hline NAA - & $159^{* *}$ & $79.3^{\mathrm{Ns}}$ & $11.5^{* *}$ & $4.7^{* * * *}$ \\
\hline+ & 140 & 79.8 & 11.2 & 3.2 \\
\hline Carbaryl - & $148^{\mathrm{Ns}}$ & $78.4^{*}$ & $11.0^{* * * *}$ & $4.7^{* * * *}$ \\
\hline+ & 151 & 80.3 & 11.7 & 3.3 \\
\hline $\mathrm{BA}-$ & $154^{\mathrm{Ns}}$ & $77.1^{* * *}$ & $11.2^{*}$ & $5.7^{* * * *}$ \\
\hline+ & 145 & 81.6 & 11.5 & 2.3 \\
\hline NAA $\times$ carbaryl & NS & NS & $* *$ & NS \\
\hline $\mathrm{NAA} \times \mathrm{BA}$ & $* * *$ & NS & $* *$ & $* * *$ \\
\hline Carbaryl $\times$ BA & $*$ & NS & $*$ & $*$ \\
\hline NAA $\times$ carbaryl $\times$ BA & NS & NS & NS & NS \\
\hline
\end{tabular}

${ }^{2}$ Treatments applied 2 June 1989 (full bloom +17 days), as a dilute spray.

Ns, ${ }^{*}, * *, * * *$ Nonsignificant or significant at $P \leq 0.05,0.01$, or 0.001 , respectively.

BA reducing seed count most dramatically.

BA retarded flesh softening during storage. NAA exacerbated softening except in combination with BA (Table 5). No treatment influenced either senescent breakdown or bitter pit plus cork spot. Treatments generally did not affect decay, except the combinations of BA plus NAA plus carbaryl or BA plus carbaryl more than doubled decay incidence relative to the control.

\section{Discussion}

BA has been an effective thinner on a variety of apple cultivars (Bound et al., 1991b; Byers and Carbaugh, 1991; Elfving, 1989; Greene and Autio, 1990). The results of this investigation confirm that it is effective on spur-type 'Delicious'.

Combination chemical thinner sprays are frequently used on difficult-to-thin cultivars and spur-type trees, similar to the 'Delicious' used in this investigation (Forshey, 1987; Looney, 1986). Generally, fruit abscission is greater following combined application of NAA and carbaryl (Grausland, 1981), but this was not confirmed in this investigation. The combination of BA and carbaryl was especially potent, since it nearly defruited spurtype 'Delicious', even when set was very heavy. Byers and Carbaugh (1991) reported strong thinning activity from several thinning combinations containing BA at $50 \mathrm{mg}^{-1 i t e \mathrm{r}^{-1}}$ plus carbaryl at $900 \mathrm{mg} \cdot$ liter $^{-1}$. Lower rates of 
Table 4. Effects of BA, NAA, and carbaryl used alone or in combination on fruit set and fruit quality of mature 'Redspur Delicious'/M.7 (1990).

\begin{tabular}{|c|c|c|c|c|c|c|}
\hline Treatment $^{2}$ & $\begin{array}{c}\text { Fruit wt } \\
\text { no pygmies } \\
(\mathrm{g})\end{array}$ & $\begin{array}{c}\text { Fruit wt } \\
\text { with pygmies } \\
(\mathrm{g})\end{array}$ & $\begin{array}{c}\text { Flesh } \\
\text { firmness } \\
(\mathrm{N})\end{array}$ & $\begin{array}{c}\text { Soluble } \\
\text { solids concn } \\
(\%)\end{array}$ & $\begin{array}{c}\text { Seed } \\
\text { count } \\
\text { (no.) }\end{array}$ & $\begin{array}{c}\text { Pygmies } \\
(\%)\end{array}$ \\
\hline Control & 145 & 145 & 75.7 & 9.9 & 6.1 & 0 \\
\hline NAA 6 mg.liter ${ }^{-1}$ & 159 & 148 & 74.8 & 10.1 & 5.1 & 11 \\
\hline Carbaryl $600 \mathrm{mg} \cdot$ liter $^{-1}$ & 171 & 171 & 76.1 & 10.6 & 4.6 & 0 \\
\hline BA $75 \mathrm{mg} \cdot \mathrm{liter}^{-1}$ & 183 & 183 & 75.7 & 10.4 & 5.6 & 0 \\
\hline BA + carbaryl & 211 & 211 & 78.9 & 11.2 & 2.7 & 0 \\
\hline $\mathrm{BA}+\mathrm{NAA}$ & 154 & 101 & 78.9 & 10.2 & 1.4 & 62 \\
\hline NAA + carbaryl & 179 & 144 & 75.2 & 10.6 & 3.3 & 29 \\
\hline BA + NAA + carbaryl & 141 & 103 & 80.7 & 10.6 & 1.1 & 54 \\
\hline \multicolumn{7}{|l|}{ Significance } \\
\hline NAA - & $177^{* *}$ & $177^{* *}$ & $76.6^{\mathrm{NS}}$ & $10.5^{* *}$ & $4.3^{* * * *}$ & $0^{* * * *}$ \\
\hline+ & 158 & 124 & 77.5 & 10.4 & 2.7 & 39 \\
\hline Carbaryl - & $160^{* *}$ & $144^{* *}$ & $76.1^{*}$ & $10.2^{* * *}$ & $4.5^{* * * *}$ & $18^{\mathrm{Ns}}$ \\
\hline+ & 175 & 157 & 77.5 & 10.7 & 2.9 & 21 \\
\hline $\mathrm{BA}-$ & $163^{*}$ & $152^{\mathrm{Ns}}$ & $75.2^{* * * *}$ & $10.3^{*}$ & $4.8^{* * * *}$ & $10^{* * * *}$ \\
\hline+ & 172 & 150 & 78.4 & 10.6 & 2.7 & 29 \\
\hline NAA $\times$ carbaryl & $*$ & $*$ & NS & $*$ & $* *$ & NS \\
\hline $\mathrm{NAA} \times \mathrm{BA}$ & $* * *$ & $* * *$ & $* *$ & $*$ & $* * *$ & $* * *$ \\
\hline Carbaryl $\times$ BA & NS & NS & NS & NS & NS & $* *$ \\
\hline NAA $\times$ carbaryl $\times$ BA & NS & NS & NS & NS & $* *$ & $* *$ \\
\hline
\end{tabular}

${ }^{2}$ Treatments applied 1 June 1990 (full bloom +21 days), as a dilute spray.

Ns, ***,*** Nonsignificant or significant at $P \leq 0.05,0.01$, or 0.001 , respectively.

Table 5. Effects of BA, NAA, and carbaryl used alone or in combination on flesh firmness and fruit disorders following storage (0C for 28 days) of mature 'Redspur Delicious'/M.7 (1990).

\begin{tabular}{|c|c|c|c|c|}
\hline \multirow[b]{2}{*}{ Treatment $^{2}$} & \multirow[b]{2}{*}{$\begin{array}{l}\text { Flesh } \\
\text { firmness } \\
\text { (N) }\end{array}$} & \multicolumn{3}{|c|}{ Fruit affected } \\
\hline & & $\begin{array}{l}\text { Senescent } \\
\text { breakdown } \\
(\%)\end{array}$ & $\begin{array}{c}\text { Decay } \\
(\%)\end{array}$ & $\begin{array}{l}\text { Bitter pit plus } \\
\text { cork spot } \\
(\%)\end{array}$ \\
\hline Control & 59.2 & 3.4 & 11.4 & 1.2 \\
\hline NAA 6 mg.liter ${ }^{-1}$ & 55.0 & 4.2 & 13.4 & 1.0 \\
\hline Carbaryl $600{\mathrm{mg} \cdot \text { liter }^{-1}}^{-1}$ & 57.3 & 9.1 & 12.8 & 2.7 \\
\hline BA $75 \mathrm{mg} \cdot \mathrm{liter}^{-1}$ & 59.6 & 4.3 & 13.3 & 6.1 \\
\hline $\mathrm{BA}+$ carbaryl & 59.2 & 7.4 & 26.1 & 3.8 \\
\hline $\mathrm{BA}+\mathrm{NAA}$ & 58.3 & 9.2 & 14.5 & 5.8 \\
\hline NAA + carbaryl & 53.2 & 7.7 & 14.9 & 2.8 \\
\hline $\mathrm{BA}+\mathrm{NAA}+$ carbaryl & 60.5 & 10.3 & 27.2 & 6.3 \\
\hline \multicolumn{5}{|l|}{ Significance } \\
\hline NAA - & $58.7^{*}$ & $6.0^{\mathrm{Ns}}$ & $15.9^{\mathrm{Ns}}$ & $3.5^{\mathrm{Ns}}$ \\
\hline+ & 56.9 & 7.8 & 17.5 & 3.9 \\
\hline Carbaryl - & $58.3^{\mathrm{Ns}}$ & $5.3^{\mathrm{Ns}}$ & $13.1^{* * *}$ & $3.5^{\mathrm{Ns}}$ \\
\hline+ & 57.3 & 8.6 & 20.3 & 3.9 \\
\hline $\mathrm{BA}-$ & $56.4^{* * * *}$ & $6.1^{\mathrm{Ns}}$ & $13.1^{* *}$ & $1.9^{\mathrm{Ns}}$ \\
\hline+ & 59.2 & 7.8 & 20.3 & 5.5 \\
\hline NAA $\times$ carbaryl & NS & NS & NS & NS \\
\hline $\mathrm{NAA} \times \mathrm{BA}$ & $*$ & NS & NS & NS \\
\hline Carbaryl × BA & NS & NS & $* *$ & NS \\
\hline NAA $\times$ carbaryl $\times$ BA & NS & NS & NS & NS \\
\hline
\end{tabular}

${ }^{2}$ Treatments applied 1 June 1990 (full bloom +21 days), as a dilute spray.

Ns, ***,****N Nonsignificant or significant at $P \leq 0.05,0.01$, or 0.001 , respectively.

these should be evaluated to determine appropriate thinning rates. NAA application can cause pygmy formation on 'Delicious' (Rogers and Williams, 1977). The effect may be synergistic when combined with carbaryl (Unrath, 1981). Both phenomena were confirmed in this investigation. We further established that the combination of BA with NAA may cause the production of a significant number of seedless pygmy fruit. Bound et al. (1991a) reported a similar observation when 'Delicious' fruit were first sprayed with Promalin at king bloom followed by NAA at $8 \mathrm{mg} \cdot$ liter $^{-1}$ applied up to 7 DAFB. Marini and Sowers (1991) described an analogous occurrence when they applied NAA as a chemical thinner on spur-type 'Delicious' trees that previously received a Promalin spray to enhance lateral branching. Promalin contains equal amounts of $\mathrm{GA}_{4+7}$ and
BA. It appears that the BA component of Promalin interacts with NAA to reduce fruit size and increase the number of seedless pygmy fruit on 'Delicious'.

A similar factorial experiment was conducted on 'McIntosh' using BA, NAA, and carbaryl (Greene and Autio, 1990). There were several important differences when compared with the results of this investigation. In that experiment, seedless pygmy fruit were not formed and NAA $\left(6 \mathrm{mg} \cdot \mathrm{liter}^{-1}\right)$ combined with carbaryl thinned to an appropriate and almost ideal level of five fruit per centimeter limb circumference. There was one significant BA $\times$ NAA interaction. Yield was reduced more when both chemicals were used together than when used individually.

Generally, there is a good relationship between fruit set and return bloom (Williams and
Edgerton, 1981). That relationship was not confirmed in this investigation. For example, fruit set following NAA application was similar to that following the combination spray containing BA, NAA, and carbaryl; however, return bloom on NAA-treated trees was less than half that of trees receiving the combination spray.

Chan and Cain (1965) first reported that the number of seeds in apples ultimately determines the amount of return bloom. In this investigation, a good relationship was found between seeds and return bloom. When analyses of covariance were done, all variation in return bloom on 'Starkrimson' and the majority of that on 'Redspur' could be explained solely by seed count the previous year. Therefore, both fruit set and seed count in those fruit must be considered when assessing the effect of chemical thinners on return bloom.

NAA reduced fruit weight in both years as a main effect. The reduction in size cannot be attributed solely to the production of pygmy fruit because NAA reduced fruit weight of 'Redspur Delicious' even after the pygmy fruit were removed.Luckwill (1953) and Marsh et al. (1960) reported a reduction in fruit growth when NAA was applied as a chemical thinner. Jones et al. (1989) and Miller (1985) confirmed that high rates of NAA, applied relatively late in the thinning period, can reduce fruit weight at harvest. Bound et al. (1991a) suggested that NAA thinning sprays may best be applied no later than 7 DAFB to decrease the risk of fruit weight reduction. Even with application of NAA as early as petal fall, Williams (1993) reported that many of the undesirable effects associated with NAA use still persisted, including a reduction in fruit weight.

Thinning treatments had a limited effect on postharvest quality. There is an inverse relationship between fruit calcium and incidence of senescent breakdown and bitter pit and cork spot (Autio et al., 1986; Shear, 1975) and a less clear but still inverse relationship between decay and fruit flesh calcium. Low seed count is a factor contributing to calcium deficiency (Bramlage et al., 1990), and all chemical thinners reduced seed count. Because treatments did not affect the storage disorders most directly related to calcium content, the apparent reduction in flesh calcium by low seed count was not severe and may not be a problem in the future. BA did increase flesh firmness relative to the control, which has been previously reported for fruit evaluated at harvest but not following storage (Greene, 1993).

\section{Literature Cited}

Autio, W.R., W.J. Bramlage, and S.A. Weis. 1986 Predicting poststorage disorders of 'Cox's Orange Pippin' and Bramley's seedling apples by regression equations. J. Amer. Soc. Hort. Sci. 111:738-742.

Bound, S.A., K.M. Jones, T.B. Koen, and M.J. Oakford. 1991b. The thinning effect of benzyladenine on red 'Fuji' apple trees. J. Hort. Sci. 66:789-794.

Bound, S.A., K.M. Jones, T.B. Koen, M.J. Oakford, M.H. Barrett, and N.E. Stone. 1991a. The inter- 
action of cytolin and NAA on cropping red 'Delicious' apple. J. Hort. Sci. 66:559-567.

Bramlage, W.J., S.A. Weis, and D.W. Greene. 1990. Observations on the relationships among seed number, fruit calcium, and senescent breakdown in apples. HortScience 25:351-353.

Byers, R.E. and D.H. Carbaugh. 1991. Effect of chemical thinning sprays on apple fruit set. HortTechnology 1:41-48.

Chan, B.G. and J.C. Cain. 1967. The effect of seed formation on subsequent flowering in apple. Proc. Amer. Soc. Hort. Sci. 91:63-68.

Elfving, D.C. 1989. N-(phenylmethyl)-1H-purine6-amine (BA) as a chemical thinner for 'Idared' apple. Acta Hort. 239:357-362.

Elfving, D.C. 1991. Benzyladenine as a chemical thinner for apple. Compact Fruit Tree 24:73-74.

Forshey, C.G. 1987. A review of chemical fruit thinning. Proc. Mass. Fruit Growers' Assn. 93:68-73.

Grauslund, J. 1981. Chemical thinning of apple cultivar 'Summerred' with NAA and carbaryl. Acta Hort. 120:77-82.

Greene, D.W. 1993. A review of the use of benzyladenine (BA) as a chemical thinner for apples. Acta Hort. 329:231-236.

Greene, D.W. and W.R. Autio. 1989. Evaluation of benzyladenine as a chemical thinner on
'McIntosh' apples. J. Amer. Soc. Hort. Sci. 114:68-73.

Greene, D.W. and W.R. Autio. 1990. Thinning activity of benzyladenine on several apple cultivars. J. Amer. Soc. Hort. Sci. 115:394-400.

Hislop, R.G. and R.J. Prokopy. 1981. Integrated management of phytophagous mites in Massachusetts (U.S.A.) apple orchards. 2. Influence of pesticides on the predator Amlyseius fallacis (Acarina: Phytoseiidae) under laboratory and field conditions. Prot. Ecol. 3:157-172.

Jones, K.M., T.B. Koen, M. Oakford, and S. Bound. 1989. Thinning Red Fuji apples with ethephon and NAA. J. Hort. Sci. 64:527-532.

Looney, N.E. 1986. Chemical thinning of apple: Some new strategies and important refinements to old procedures. Acta Hort. 179:597-604.

Luckwill,L.C. 1953. Studies of fruit development in relation to plant hormones. II. The effect of naphthalene acetic acid on fruit set and fruit development in apples. J. Hort. Sci. 28:25-40.

Marini, R.P. and D. Sowers. 1991. Growth, yield, and fruit weight of spur-bound 'Delicious' apple trees following spur-pruning and BA plus $\mathrm{GA}_{4+7}$ application. J. Amer. Soc. Hort. Sci. 116:454 459.

Marsh, H.V., F.W. Southwick, and W.D. Weeks. 1960. The influence of chemical thinners on fruit set and size, seed development, and preharvest drop of apples. Proc. Amer. Soc. Hort. Sci. 75:5-21.

McLaughlin, J.M. and D.W. Greene. 1984. Effects of BA, $\mathrm{GA}_{4+7}$ and daminozide on fruit set, fruit quality, vegetative growth, flower initiation and flower quality of 'Golden Delicious' apples. J. Amer. Soc. Hort. Sci. 109:34-39.

Miller, P. 1985. Apple thinning in Australia. Hort. Res. Inst., Knoxfield, Victorian Dept. of Agr. and Rural Affairs.

Rogers, B.L. and G.R. Williams. 1977. Chemical thinning of spur-type 'Delicious' apple trees. Va. Fruit 65:23-28.

Shear, C.B. 1975. Calcium-related disorders of fruits and vegetables. HortScience 10:361-365.

Unrath, C.R. 1981. An overview of environmental factors affecting orchard growth regulator response with special reference to apples. Acta Hort. 120:43-52.

Williams, M.W. 1979. Chemical thinning of apples. Hort. Rev. 1:270-300.

Williams, M.W. 1993. Comparison of NAA and carbaryl petal-fall sprays on fruit set of apples. HortTechnology 3:428-429.

Williams, M.W. and L.J. Edgerton. 1981. Fruit thinning of apples and pears with chemicals. Agr. Info. Bul. 289. 